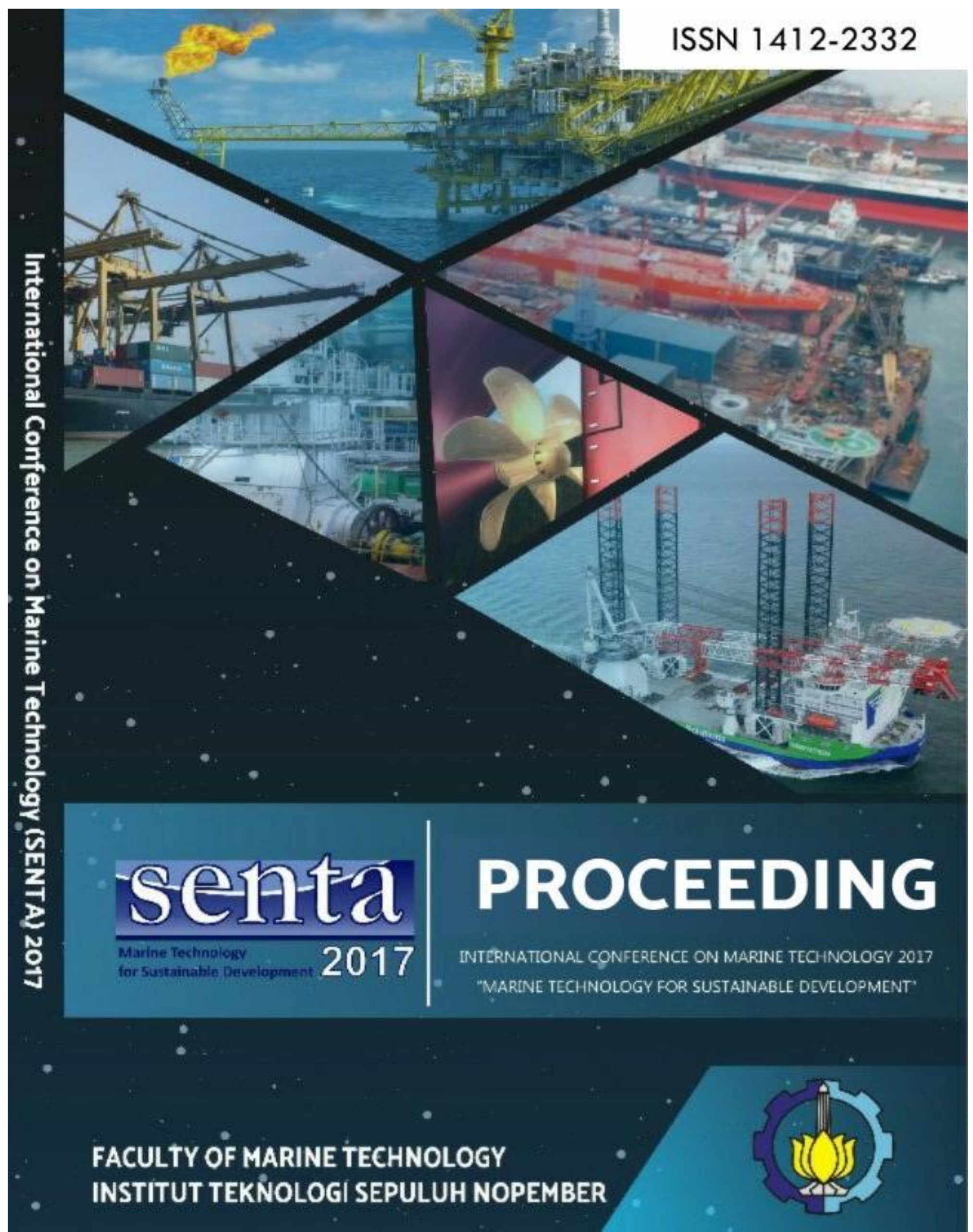




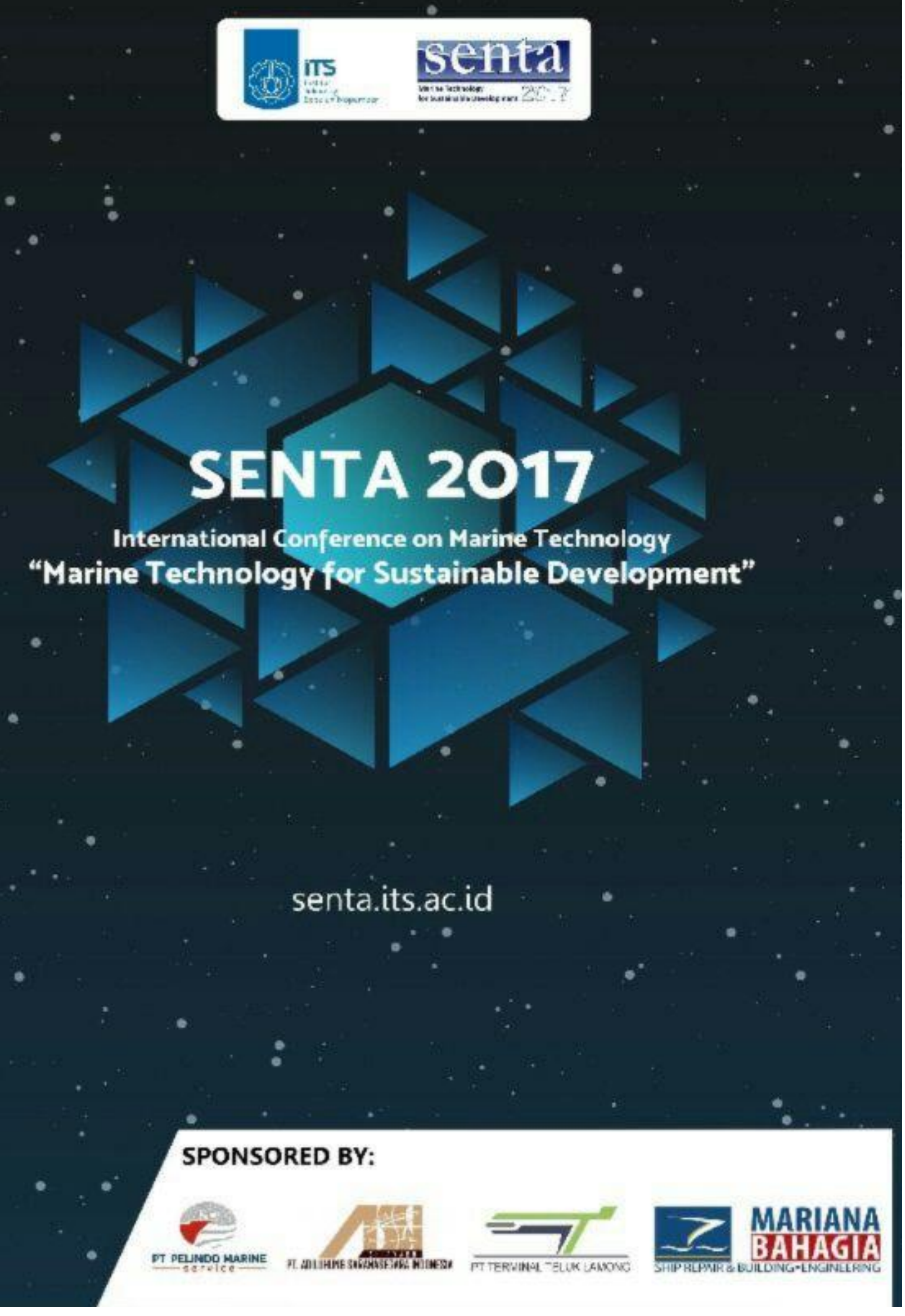




\section{CONTENT}

Opening Speech By Rector ITS.........................................i

Opening Speech By Dean of Faculty of Marine Technology ITS.............ii

List of Committee........................................................iii

Contents..................................................................

\section{MARINE ENGINEERING FULL PAPER}

FINANCIAL RISK ANALYSIS OF SHIP PROCUREMENT (NEW BUILDING, USED, CHARTER)

Widhana Fajar Kussuma, Raja Oloan Saut Gurning, A. A. Bagus Dinariyana Dwi P.

TECHNICAL OVERVIEW OF BIOGAS UTILIZATION AS FUEL OF BOAT ENGINE

Nilam Sari Octaviani ,Semin

SELECTION OF LNG PLANT LOCATION USING MULTI ATTRIBUTE DECISION MAKING (MADM) METHOD

Nurhadi Siswantoro, Muhammad Badrus Zaman, Semin, Dwi Priyanta.... $. . \mathrm{I}-15$

THE IMPLEMENTATION OF ENGINE TELEMETRY DATA TO THE IMPROVEMENT OF A DUAL FUEL DIESEL ENGINE MAINTENANCE SCHEME

Fadilla I. Prastyasari, M. Badrus Zaman. ..I-24

OPTIMIZE AIR VENTILATION ARRANGEMENT USING CFD MODEL TO MAINTAIN THE ENGINE ROOM TEMPERATURES OF AN 8000 DWT GENERAL CARGO

Agoes Santoso, Alam Baheramsyah, M. Ramadhani Nugraha.

$. \mathrm{I}-30$

IMPLEMENTATION OF FORMAL SAFETY ASSESSMENT FOR RATIFICATION CONSIDERATION OF CLC 1969 AND FUND CONVENTION

Trika Pitana, Dhimas Widhi Handani, Bernadita Suryawati. I-36 
PRELIMINARY STUDY OF THE USING OF CRUMB RUBBER FILTRATION AND UV RADIATION AS MEDIUM FOR TREATING SHIP'S BALLAST WATER

Trika Pitana,Maya Shovitri,Haris Nur Fauzi $\mathrm{I}-45$

A FUZZY DECISION SUPPORT SYTEM OF IUU - TRANSHIPMENT IN INDONESIA Aulia Siti Aisjah, A.A. Masroeri, Moch. Yusuf Santoso, Syamsul Arifin, and Achmad Nidzal Alif. I-53

DESIGN OF DUAL FUEL SYSTEM FOR MAIN ENGINE ON CNG CARRIER VESSEL Adhi Iswantoro, M. Badrus Zaman, Semin, Indra Ranu Kusuma.... I-61

THE INVESTIGATION ELECTRICAL POWER CONSUMPTION ON PASSENGER SHIP KM BUKIT SIGUNTANG

Sardono Sarwito, Semin, M Badrus Zaman

REVIEW OF LED SUPREMACY ON THE PURSE SEINE FISHING VESSEL

Eddy Mustono, Eddy Setyo Koenhardono. $\mathrm{I}-80$

THE EXPERIMENTAL WORKS OF SHIP'S HULL COATING USING SUPERHYDROPHOBIC TO REDUCE FRICTIONAL RESISTANCE

Alam Baheramsyah, Agoes Santoso, Tony Bambang M., and Trisno Kusuma S $\mathrm{I}-90$

STUDY ON IMPROVEMENT OF PRODUCTIVITY OF INDONESIA SHIPBUILDING WITH THEORY OF CONSTRAINTS

Hirofumi Doi,Takeshi Shinoda I-97

OPTIMIZATION OF BUOYWEATHER MODELS USE OF PSO METHOD: High Reliability in Java Sea as Maritim Weather Station

Syamsul Arifin, Aulia Siti Aisjah, and Nuri Sabrina I-104

\section{APPLICATIONS OF HYBRID PROPULSION SYSTEM ON TRIMARAN TOURIST VESSELS WITH RELIABLE AND ENVIRONMENTAL FRIENDLY}

Eddy Setyo Koenhardono 
NAVAL ARCHITECTURE AND SHIPBUILDING ENGINEERING FULL

PAPER

RESISTANCE ANALYSIS OF HYDROFOIL SUPPORTED CATAMARAN USING COMPUTATIONAL FLUID DYNAMICS

Ketut Suastika, Regi Y. Dikantoro, Dedi B. Purwanto, Dony Setyawan and Wing H. A. Putra....

SUBMERGED RESISTANCE ANALYSIS OF MINI SUBMARINE USING COMPUTATIONAL FLUID DYNAMICS

Gita Marina Ahadyanti, Wasis Dwi Aryawan, and Muhamad Fyan Dinggi.... II-10

DESIGN INNOVATION OF 600 GT LIVE FISH CARRIER FOR 716 AND 717 FISHING AREA OF INDONESIAN WATERS

Hasanudin, Wasis Dwi Aryawan, Danu Utama, Febriani Rohmadhana. II-19

PROPERTIES OF SANDWICH PANEL CORE FROM EGGSHELL POWDER FOR SHIP STRUCTURE

Id Adha Mula, A. Zubaydi and A. Budipriyanto.

TESTS ON SANDWICH PLATE CORE MATERIALS WITH RICE HUSK FILLER FOR SHIP DECK STRUCTURE

Yudiono, A. Budipriyanto, A. Zubaydi. II-35

ECO-FRIENDLY CATAMARAN BOAT FOR TOURISM AND TRANSPORTATION AT LAKE OF BATUR - BALI

I K A P Utama, A A B D Putranta, I M Ariana, Hasanudin, D Purnamasari, I K Suastika... II-42

STUDY ON WOOD SAWDUST FOR SANDWICH CORE MATERIAL OF SHIP STRUCTURE

M. S. Purwoko, A.Budipriyanto, A.Zubaydi. II-50

DEVELOPMENT OF SANDWICH PANEL WITH CORE FROM CLAMSHELLPOWDER FOR SHIP STRUCTURE

K. Abdullah, A. Zubaydi and A. Budipriyanto. II-59 
ANALYSIS OF STABILITY, RESISTANCE AND SEAKEEPING ACCORD TO DIMENSION AND FORM OF FISHING VESSEL 30 GT

Shanty Manullang, Arif Fadillah, Rizky Irvana..... II-68

ANALYSIS OF SELF PROPELLED BARGE RESISTANCE ON SHALLOW WATERS USING CFD

Erzad Iskandar Putra,Ir. Wasis Dwi Aryawan II-76

DESIGN OF SHIPBUILDING MATERIAL MANAGEMENT ANDROID-BASED APPLICATION

Moh. Sholikhan Arif, Triwilaswandio Wuruk Pribadi, Heri Supomo, Swastriadi Wirayudha.II-84

ANALYSIS OF STRESS DUE TO WAVE LOAD ON THE CORVETTE WARSHIP

Pratama Yuli Arianto, Aries Sulisetyono,Teguh Putranto.... $. \mathrm{II}-91$

ULTRASONIC TESTING TECHNIQUES FOR DIFFERENT THICKNESS BASE METAL WELD AREA AT SHIP ENGINE ROOM FOUNDATION

Try Arismunandar and Wing Hendroprasetyo Akbar Putra II-99

THE EFFECT OF COVER DIMENSION OF TRIMARAN HULLS GAP ON THE RESISTANCE, CASE STUDY ON FLOATING PORT DESIGN

E.R. de Fretes, E.J. de Lima .II-116

REVIEW OF CORRELATION BETWEEN MARINE FOULING AND FUEL CONSUMPTION ON A SHIP

M. L. Hakim, I K. A. P. Utama, B. Nugroho, A. K. Yusim, M. S. Baithal, I K. Suastika.....II-122

THE EFFECT OF DRAFT CHANGING TO SHIP SPEED

Wolter R. Hetharia.

$. \mathrm{II}-130$

DESIGN AND STRUCTURE ANALYSIS OF RAMP DOOR USING FINITE ELEMENT METHOD

Ardi Nugroho Yulianto and Dedi Budi Purwanto. II-139 
THE POTENCY OF PINEAPPLE LEAF FIBER AS AN ALTERNATIVE COMPOSITE MATERIAL TO SUBTITUTION FIBERGLASS IN THE HULL MANUFACTURE

LesianaY. Ningrum, Amiadji, Tony B. Musriyadi, Edi Jadmiko. II-144

ALTERNATIVE HULL FORM ANALYSIS OF SELF PROPELLED BARGE TO REDUCE SHIP RESISTANCE

Febriani Rohmadhana, Wasis Dwi Aryawan.

II-157

DESIGN FOR PRODUCTION AND OPERATION FOR TRADITIONAL FISHING BOAT BASED ON LOCAL WISDOM (Case Study: Gresik \& Banyuwangi)

Supomo H., Baihaqi , Zubaydi, Wuruk Pribadi , Imam Wahidi. II-166

TECHNICAL ANALYSIS OF COMPOSITE MATERIALS OF NATURAL SUGARCANE FIBER SUPPLIES FOR ALTERNATIVE MATERIALS OF SHIP HULL MAKING

Retno pujiati, Amiadji1, Edi jatmiko, Tony Bambang Musriyadi II-173

\section{OCEAN ENGINEERING FULL PAPER}

ASSESSMENT OF TSUNAMI HAZARD VULNERABILITY: CASE STUDY OF THE 1994 BANYUWANGI TSUNAMI

Devi Verawati Gusman, Kriyo Sambodho and Inovasita Alifdini III-1

\section{PORTS FULL PAPER}

EVALUATION OF CONTAINER TERMINAL CONFIGURATIONS BY COMPUTER SIMULATION

Takeshi Shinoda, Hideyo Inutsuka,Putu Hangga, TiagoNovaes Mathias .... IV-1

COMPETITIVENESS ANALYSIS AMONG CONTAINER TERMINALS IN ONE REGION: A CASE STUDY OF CONTAINER TERMINALS IN SURABAYA

Firmanto Hadi, Siti Dwi Lazuardi, Besti Pratiwi $\mathrm{IV}-12$ 
STUDY OF PORT DEVELOPMENT IMPACT ON TRANSPORT COST: A CASE STUDY OF TELUK PRIGI PORT

Christino Boyke S.P, Ferdhi Zulkarnaen,Norma Syahnasa.............................IV-20

MARINE RENEWABLE ENERGY FULL PAPER

CONCEPT DEVELOPMENT OF ARTICULATED TOWER - OCEAN WAVE ENERGY CONVERTER (AT-OWEC)

Eko B. Djatmiko, Nur Syahroni, Sujantoko, Danil T Putra, and Imam F Farkhani............ -1

APPLICATION OF ORGANIC RANKINE CYCLE POWER PLANT ON COASTER 1000 DWT

Ayom Buwono, Muswar Muslim, and Danny Faturachman $\mathrm{V}-12$

IDENTIFICATION AND MAPPING A POTENSIAL WAVE ENERGY LOCATION IN INDONESIAN WATERS

Fahreza Okta S, Mukhtasor ..V-21

SURFACE CURRENTS IN INDONESIAN SEA BASED ON OCEAN SURFACE CURRENTS NEAR - REALTIME (OSCAR) DATA

Muchammad Iqbal Havis, Nurul Fatimah Yunita. V-27

SOLAR POWER ENERGY MODEL - STUDY CASE AT GILIYANG ISLAND

Ede Mehta Wardhana, Muhammad Badrus Zaman, Semin .. -32

NUMERICAL STUDY OF SAVONIUS WATER TURBINE PERFORMANCE BY ADDING DEFLECTOR TO ADVANCING BLADE SIDE

Priyo Agus Setiawan, Adi Wirawan Husodo, Anda Iviana Juniani $\mathrm{V}-43$

ANALYSIS OF THE DEEP WATER MOORING SYSTEM PLATFORM

Achmad Baidowi, Semin* and Arif R Suwandi V-50 
CONFIGURATION SELECTION BASED ON LIFECYCLE COST OF SUBSEA PRODUCTION SYSTEM: CASE OF INDONESIAN DEEPWATER FIELD

C FB Sa'u, D M Rosyid V-59

OVERVIEW OF OPPORTUNITY OF DUAL FUEL SHIP TO SUPPORT BLUE ECONOMY INDONESIA STRATEGY

Frengki M. Felayati, Semin and Saut Gurning. V-70

\section{MARITIME LOGISTICS FULL PAPER}

TOL LAUT IMPLEMENTATION FOR VESSEL CALLED AT AMBON: A REVIEW

IG.N. Sumanta Buana, Setyo Nugroho, Firmanto Hadi and Irwan Tri Yunianto. VI-1

IMPROVING EFFECTIVENESS OF REFRIGERATED FISH HOLD TECHNOLOGY IN THE NATIONAL LOGISTIC SYSTEM: IDENTIFYING STRATEGY FOR ITS APPLICATION IN THE FIELD

Atikah Nuhayati, Agus Heri Purnomo VI-10

CO-MANAGEMENT DEVELOPMENT MODEL IN THE COASTAL REGION BASED ON BLUE ECONOMY

Hayy Nur Abdillah, R. O. Saut Gurning VI-20

THE IMPORTANT ROLE OF PANGLIMA LAOT (SEA COMMANDER) AS A LOCAL WISDOM IN SUSTAINABLE FISHERIES MANAGEMENT IN ACEH PROVINCE

Nazaruddin , Saut Gurning VI-28

A REVIEW OF APPLICATION OF BLUE ECONOMY AS A DEVELOPMENT CONCEPT FOR SMALL AND OUTER ISLAND IN INDONESIA, CASE STUDY: NATUNA ISLAND

Thariq A. Akbar, Raja Oloan Saut Gurning. . VI-40 
IMPLEMENTATION OF THE BLUE ECONOMIC SYSTEM FOR INDONESIA'S FISHERY SECTOR

Yulia Ayu N., Saut Gurning VI-53

CUSTOMARY LAW IN INDONESIA, DO THEY HAVE A ROLE IN THE EFFORT TO CONSERVE FISHERY RESOURCES? STUDY CASE AWIG AWIG IN NORTH LOMBOK

Birham Hermansyah, R.O Saut Gurning. VI-60

PRELIMINARY STUDY OF ENERGY SUPPLY ELECTION TO THE AREA OF THE ISLANDS

Edwin Matatula, Setyo Nugroho. VI-67

MULTIMODAL TRANSPORTATION MODEL FOR HEAVY LIFT CARGO: A CASE STUDY OF EXPORT RAILWAY CARRIAGES

Hasan Iqbal Nur, I G. N. Sumanta Buana,Amallia Pertiwi VI-76

MULTIMODAL TRANSPORTATION MODEL FOR HEAVY LIFT CARGO: A CASE STUDY OF EXPORT RAILWAY CARRIAGES

Hasan Iqbal Nur, I G. N. Sumanta Buana,Amallia Pertiwi VI-84

SUSTAINABLE INDONESIAN ECONOMIC DEVELOPMENT IN THE FISHERIES SECTOR WITH BLUE ECONOMIC CONCEPT

Otto Senna , Saut Gurning. VI-91

CONCEPTUAL DESIGN AND OPERATION MODEL OF FLOATING HEALTH CLINIC

Tri Achmadi, Eka Wahyu Ardhi,Muchammad Khoiruddin.Mz .VI-96

\section{COASTAL AND NATURAL RESOURCES MANAGEMENT FULL PAPER}

ZONATION BASED SPATIAL DYNAMIC MODEL APPROACH FOR SUSTAINABLE MANAGEMENT OF COASTAL AREAS OF AMBON CITY

Pieter Th Berhitu, Supriharyono, Djoko Suprapto VII-1 
COMPARISON STUDY OF Skeletonema sp. AND Chaetoceros sp. ABILITIES AS BIOREMEDIATION AGENT OF MERCURY (Hg)

Rikky Leonard, Endang Dewi Masithah, Wahju Tjahjaningsih. VII-12

SUSTAINABILITY CHECKLIST FORTRANSPORT SYSTEM PLAN FOR MANGROVE ECO-PARK

Mohd Zamani, Ahmad, Syed Ahmad Iskandar Syed Ariffin, Ahmad Faizal Ahmad Fuad, Asmawi Abdul Malik, Ismail Zainol.... VII-21

\section{DISTRIBUTIONS OF DIATOM PHYTOPLANKTON BASED ON SEA CURRENT IN INDONESIA}

Thesyandra Mira Anissabela Rigitta, Gabriella Inez Aramita VII-28

\section{DISPERSION ESTIMATION OF SHIP GAS EMISSION USING LAGRANGIAN PARTICLE DISPERSION MODEL (LPDM) BASED ON AUTOMATIC} IDENTIFICATION SYSTEM (AIS): A CASE STUDY OF MADURA STRAIT

Alphie Benhard Manullang, A.A.B. Dinariyana, Ketut Buda Artana, Fatiya Sarasvatiand Trika Pitana. VII-33

DEVELOPMENT OF DIGITAL EDUCATION FOR SMALL ISLAND CASE STUDY: MARATUA ISLAND

Muhammad Badrus Zaman, Setyo Nugroho, Murjito .VII-46

GROWTH AND PRODUCTION OF SEAGRASS LEAVES Thalassia hemprichii ON THE SULI COASTAL WATERS, AMBON ISLAND

Charlotha I Tupan, Prulley A Uneputty VII-51

MODELING OF TSUNAMI MITIGATION IN LOSARI BEACH

Andi Mega Mustika Natsir, Kriyo Sambodho ,Achmad Yasir Baeda... VII-60

STUDY ONDEVELOPMENT GREEN SHIPBUILDING INDUSTRY IN LAMONGAN DISTRICTTO INCREASE COMPETITIVENESS

Septiyan Adi Nugroho, Mahirul Mursid, Murdjito VII-67 
ECONOMIC EVALUATION AND GAS EMISSIONS FOR COAL TRANSPORTATION USING PUSHER BARGE SYSTEM AND EMPTY BARGES PLACEMENT AT PORT

Arif Fadillah, Putra Pratama

VII-78

\section{MARITIME TOURISM FULL PAPER}

FISHERY OR TOURISM DEVELOPMENT ? REVIEW OF BLUE ECONOMY CONCEPT FOR INDONESIA

Dicky Nalendra S., Saut Gurning

VIII-1

BLUE ECONOMY IMPLEMENTATION ON THE MARITIME TOURISM IN DULLAH ISLAND

Donny Endra Prastya, Saut Gurning VII-13

DEVELOPMENT OF MARINE AND COASTAL TOURISM - BASED ON BLUE ECONOMY

Dimas Tegar R, Saut Gurning..... VII-21

\section{MARITIME SECURITY AND DEFENSE FULL PAPER}

HOW DOES THE PASSENGER PERCEPTIONAWARE TO THE SAFETY ASPECTS IN CASE ON PASSENGER SHIP ?

Antoni Arif Priadi, Imam Fachrudin, Lili Purnamasita ,Retno Sawitri Wulandari, and Vidya Selasdini. IX-1 


\title{
NUMERICAL STUDY OF SAVONIUS WATER TURBINE PERFORMANCE BY ADDING DEFLECTOR TO ADVANCING BLADE SIDE
}

\author{
Priyo Agus Setiawan $^{1 *}$, Adi Wirawan Husodo ${ }^{1}$ and Anda Iviana Juniani ${ }^{1}$ \\ ${ }^{1}$ Marine Engineering, Shipbuilding Institute of Polytechnic Surabaya \\ Jalan Teknik Kimia, 60111 Keputih, Surabaya, Indonesia \\ *Email: priyo.as@ppns.ac.id \\ Phone: +62315947186; Fax: +62315942887
}

\begin{abstract}
As one of the best renewable energy sources, hydropower becomes more predictable source compared to wind energy and Savonius which its performance does not contingent to fluid flow direction. In this present, computational Fluid Dynamics acomplished by Finite Volume Method and unsteady RANS equation were applied to analyze the numerical simulation. The present study investigated the performance of Savonius Turbine by adding deflector plate installed to advancing blade side at 5, 10, 15, 30 and 45 of deflector angles in the direction of the fluid flow. The viscous turbulence model used realizable k-epsilon (RKE) and its descritization used second order upwind. The type of mesh was made from coarse to fine meshing with 8 (eight) types of meshing and the grid independency of the numerical simulation had been validated by the publish experimental data at TSR of 1,078. Grid independency occured at meshing G with the error lower than $5 \%$ compared to published experimental data. The result of this study shows that the performance of Savonius turbine increased by adding deflector in advancing blade side with the maximum torque and power coefficient at 30 of deflector angle.
\end{abstract}

Keywords: Computational Fluid Dynamics, Savonius turbine, Deflector angle, RKE

\section{INTRODUCTION}

Types of turbine are generally divided into two, vertical axis turbines (VATs) and horizontal axis turbines (HATs), based on the alignment of shaft between their axis of rotation and water direction. VATs are used to generate small scale power because the turbine performance does not depend on the fluid flow direction (Yang B et al, 2011). Type of VATs generates torque through combining drag effects and side forces. Energy of hydro from river, sea current, waves are the best renewable energy sources and very predictable compared to wind energy or the other. The application of vertical axis turbine is generally Savonius turbine, helical turbine and Darrieus turbine (Golecha et al, 2012).

An experimental investigation on the performance of the improvement of the modified Savonius rotor by providing a deflector plate on returning blade side was carried out by Golecha et al. in 2011. Position of the deflector plate was identified in their study for giving the maximum coefficient of power. The results showed that the deflector plate could increase the power coefficient by $50 \%$ for a single stage modified Savonius rotor at optimal position. Maximum power coefficient improved by $42 \%$, $31 \%$, and $17 \%$ with deflector plate for two stages 0 phase shift, 90 phase shift, and three stage modified Savonius rotor. The next experimental research from Golecha et al (2012) was carried out to investigate the performance of Savonius water turbine using two deflectors placed on advancing blade side and in front of the returning blade. 
The method used was experimentally on single stage by modifying Savonius rotor in an open water channel at a Reynolds number of $1.32 \times 10^{5}$, based on the diameter of the rotor. The maximum power coefficient of single stage of modified Savonius rotor was 0.14 at a tip speed ratio of 0.7 without adding deflector plate. Placing the deflector plate on the returning blade side could improve the power coefficient of the modified Savonius rotor to 0.21 at a tip speed ratio of 0.82 . The two deflectors placed at two positions could increase the performance of Savonius turbine. Flow phenomenon through the advancing blade, increased the drag force, using two deflectors. The flow on returning blade was decreased by deflector placed in front of the returning blade. However the difference drag between advancing blade and returning blade produced maximum torque at Savonius rotor. (Golecha et al, 2012).

Savonius turbine performance was observed by changing the velocity which obtained maximum torque coefficient at overlap ratio (e) 0.2 (Patel et al, 2013). The same research was done towards Savonius turbine using deflector in front of turbine of returning blade and beside of advancing blade. Developing of Vertical Axis Marine Current Turbine (VAMCT) had been carried out by investigation on low current condition. The experimental method had been carried out at range of overlap ratio 0.20.25 and the result of best performance occured at overlap ratio 0.21 (Yaakob et al, 2013).

This numerical simulation has been conducted to avoid uncertainty, however it produced some numerical simulation policies. The policy is very important to improve the result of numerical as discretization second order upwind and compare the numerical towards experimental data (Freitas et al, 1999). The comparison of 2-D simulation and 3-D simulation has shown great approach of experiment's result. The result of 2-D simulation has coefficient power which was closer to experiment than 3-D simulation (Hyun et al, 2012). The Spalart-Allmaras (SA) turbulence viscosity model is a one-equation turbulence model which is near with wall gradients of the transported variable, is much smaller than the turbulent kinetic energy equation based k- models (Spallart et al, 1992). The standard k- model (Launder Spalding et al, 1972) is more suitable when flow is fully turbulent and has given better results than SA model for turbine analysis (Pope, 2010). Previous studies for Savonius turbine have shown that two dimensional simulations gave acceptable results. (Yang et al, 2011, Tian et al, 2014 and Mc. Tavish et al, 2012).

In this present study, The deflector directed the fluids flow to increase flow velocity over Savonius turbine and applied the deflector to Savonius turbine with the function to add positive torque to advancing blade side. The deflector plate affected on the turbine performance and it obtained the performance of Savonius turbine as function of torque coefficient and power coefficient. The numerical simulation in this study analyzed the unsteady flow around the Savonius turbine by changing deflector angle placed in advancing blade side.

\section{NUMERICAL SIMULATION}

The present study used numerical simulation with Savonius turbine as model. Savonius model has two blades with 1 (one) meter of the diametre Savonius turbine. Unsteady incompressible Reynolds-Averaged Navier-Stokes (RANS) equation was used based on the cell-centered finite volume method and implemented the rotation by using the sliding mesh technique to rotate the space of turbine area. The structured grid was employed to all the grid system of rotor and the computational domain reached 
to $22 \mathrm{D}$ in the inlet direction, 44D in the outlet direction and 22D in the vertical direction, where D denoted the diametre of Savonius turbine. The calculations were made based on the 2-dimensional unsteady flow assumption for its relative simplicity. The mesh characteristics of numerical simulation is shown in Figure 1.

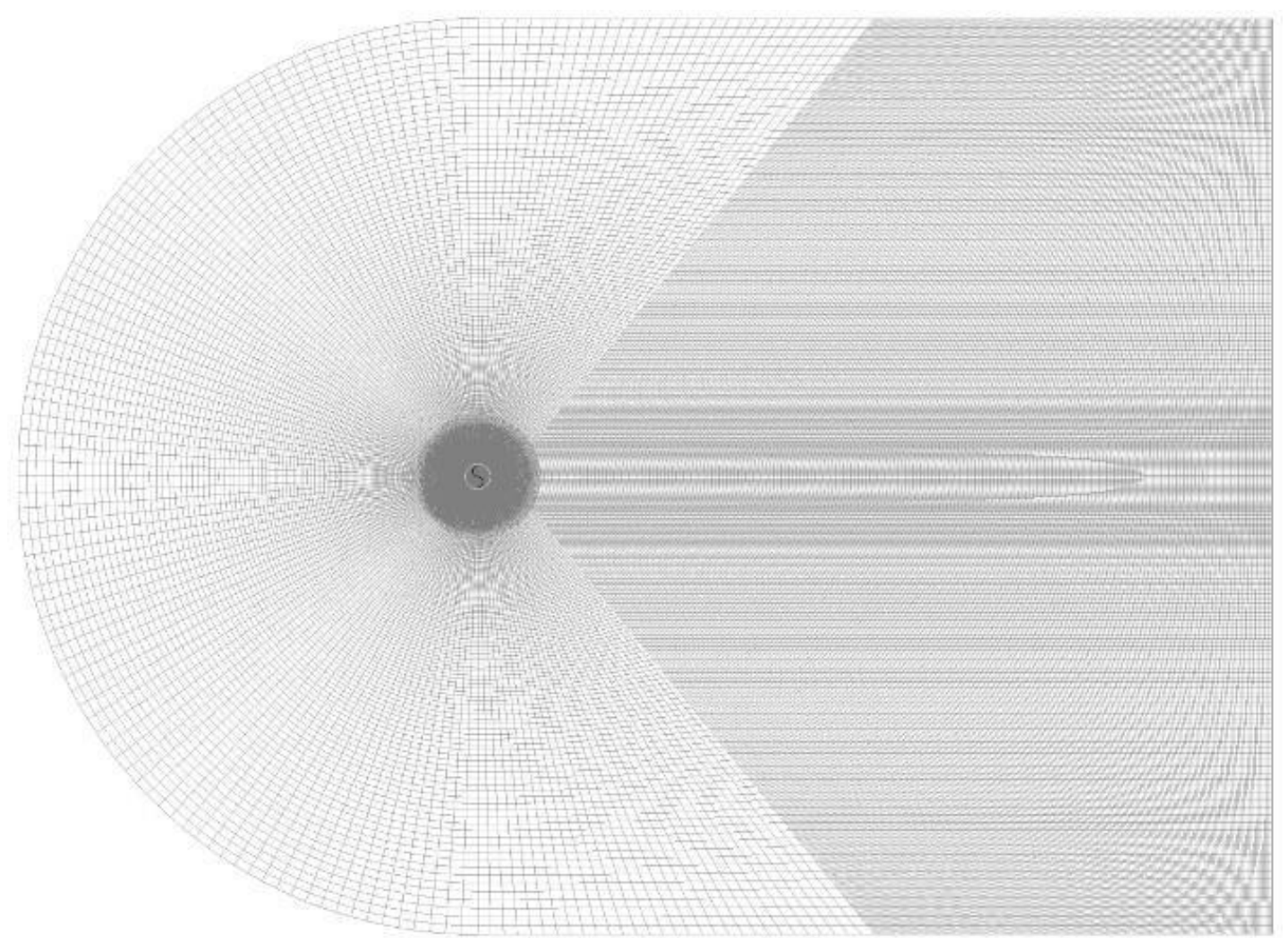

a)

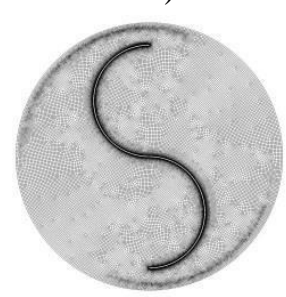

b)

Figure 1. Mesh characteristics of the (a) fixed domain, (b) rotating domain

Grid Independency investigated the changing size grid from coarse to fine. The objective of grid independency was to determine the meshing of simulation that the numerical simulation did not influence the result of simulation. The grid independency was obtained by using Blackwell experimental data without deflector or conventional Savonius rotor. It was installed in front of the returning blade without overlap ratio. The value of torque coefficient $(\mathrm{Cm})$ referred to Blackwell experimental data at a tip speed ratio (TSR) of 1.078 with value of Torque Coefficient $(\mathrm{Cm})$ was $0.185,7 \mathrm{~m} / \mathrm{s}$ of free stream velocity, and diameter of Savonius turbine was 1 (one) $\mathrm{m}$ with angular velocity of $144.087 \mathrm{rpm}$. The grid independency was carried out 8 (eight) times from coarse meshing to fine meshing. The result of grid independency is shown in Figure.2. Grid 
independency occured at Meshing type of $G$, which the simulation did not influence numerical simulation result.

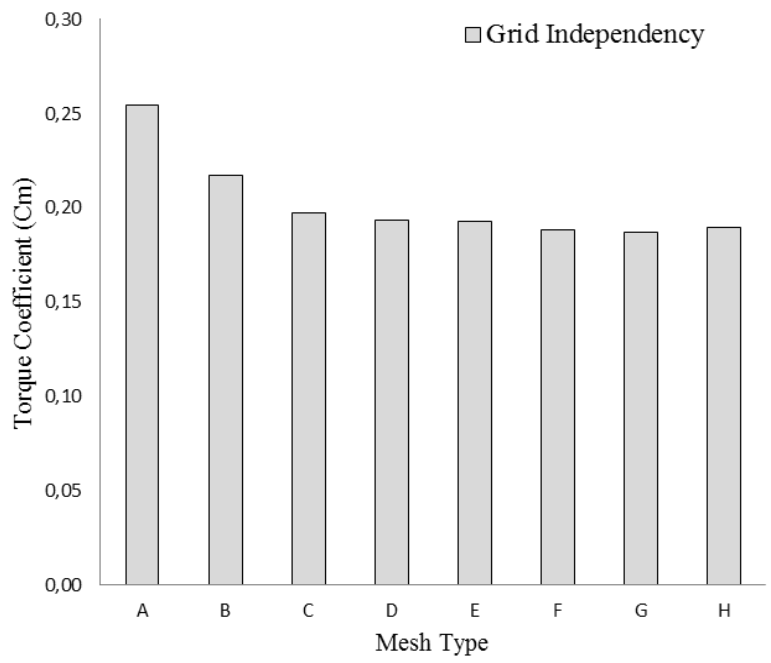

Figure 2. Study of grid-independency for the torque coefficient

The validation of Numerical Simulation was carried out by comparing publish experimental results with the air fluid for one stage conventional Savonius turbine by Blackwell as shown in Figure 3. The numerical taken from experimental data at free stream velocity kept constant in about $7 \mathrm{~m} / \mathrm{s}, 1 \mathrm{~m}$ rotor of diameter, and $0.3,0.5,0.7$, $0.9,1.1$ and 1.3 of varying TSR. In this present study, graphics of numerical simulation are similar to graphic of Blackwell experimental data, without overlap ratio for all tip speed ratio (TSR) which was employed to analyze the configuration of Savonius turbine. Figure. 3 shows that the numerical simulation result is in very good agreement with the publishing experimental data when the turbulence model used Realizable kepsilon. TSR equals to U/V, where $\mathrm{U}$ is defined as tip peripheral velocity of the rotor equal to $R$. is defined as the velocity angular of blade, $R$ is defined as the radius of rotor, and $\mathrm{V}$ is defined as the free stream velocity that kept constant in about $7 \mathrm{~m} / \mathrm{s}$. The maximum error occured at a tip speed ratio (TSR) of 0.55 to 0.65 , where the numerical simulation result was about $5 \%$ lower than Blackwell experimental data.

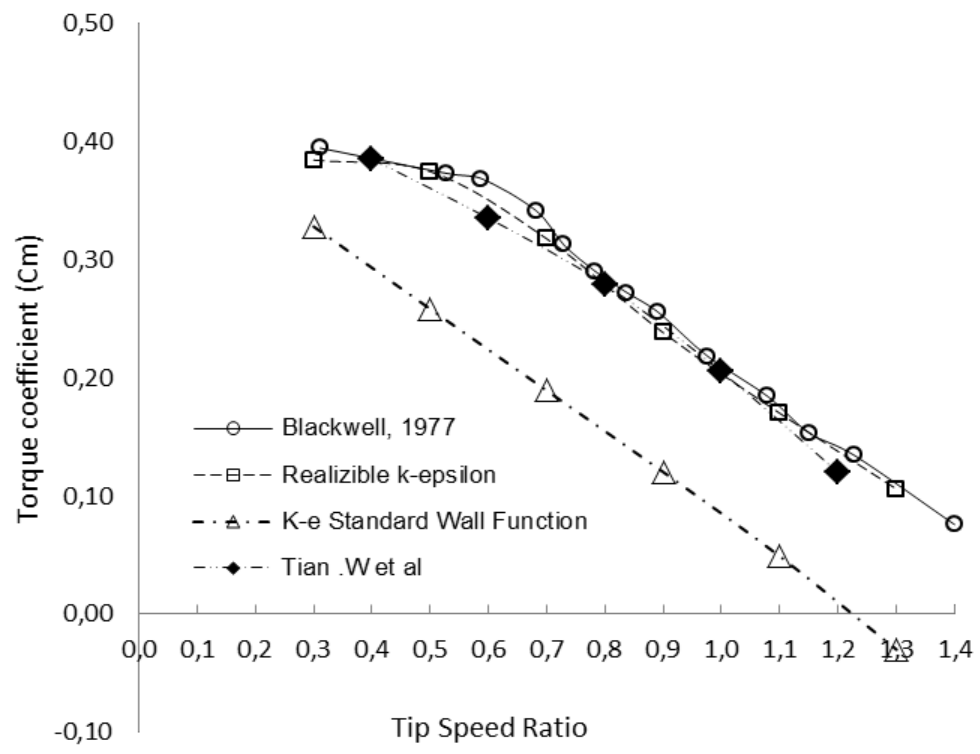

Figure 3. Tip speed ratio (TSR) as the function of Torque Coefficient $(\mathrm{Cm})$ 


\section{RESULTS AND DISCUSSION}

In this present study, The result of grid independency was obtained by changing properties of fluids from air to water fluids at free stream velocity kept constant in about $0.22 \mathrm{~m} / \mathrm{s}, 0.4 \mathrm{~m}$ rotor of diameter, 1 of X/D, 1 of Y/D and 0.3, 0.5, 0.7, 0.9, 1.1 and 1.3 of varying TSR. The geometry of this study used deflector to advancing blade side as shown in figure 4.

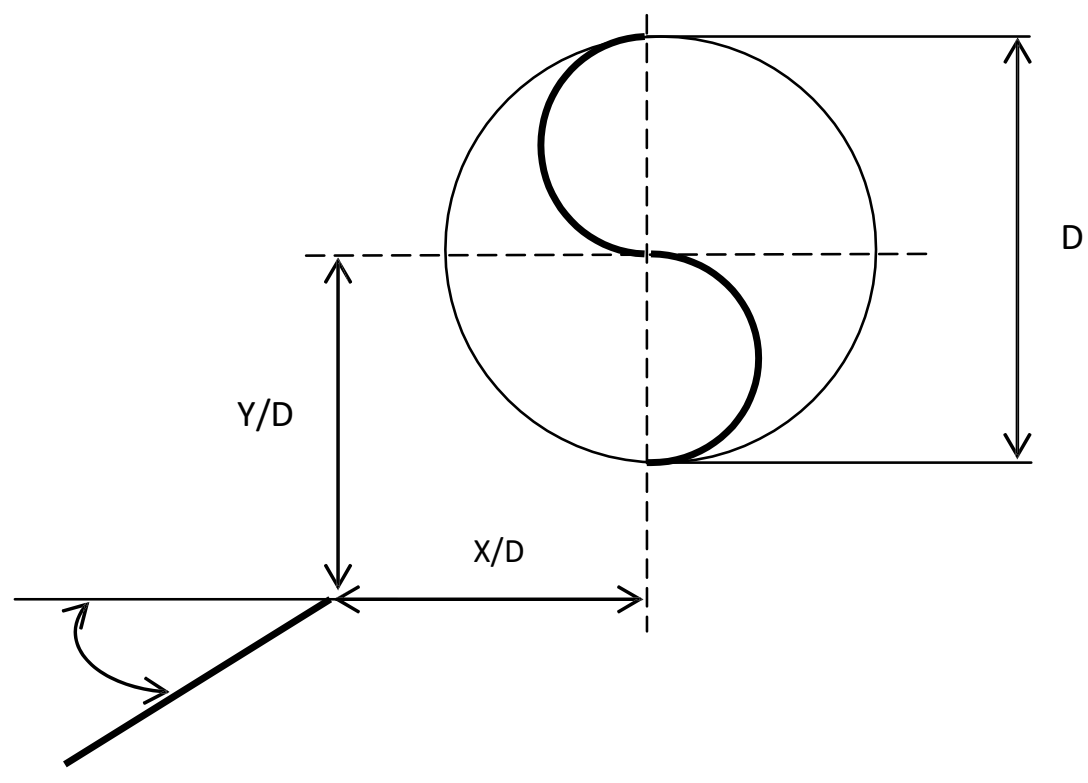

Figure 4. The geometry of Savonius turbine with deflector

The result of numerical simulation was the Tip speed ratio (TSR) as function of torque coefficient as shown in figure 5. The value of torque coefficient increased with the increasing of deflector angle at 30 degree. Meanwhile, the value of torque coefficient decreased with the increasing of deflector angle at 45 degree.

\section{Cm vs TSR at $Y / D=1, X / D=1$}

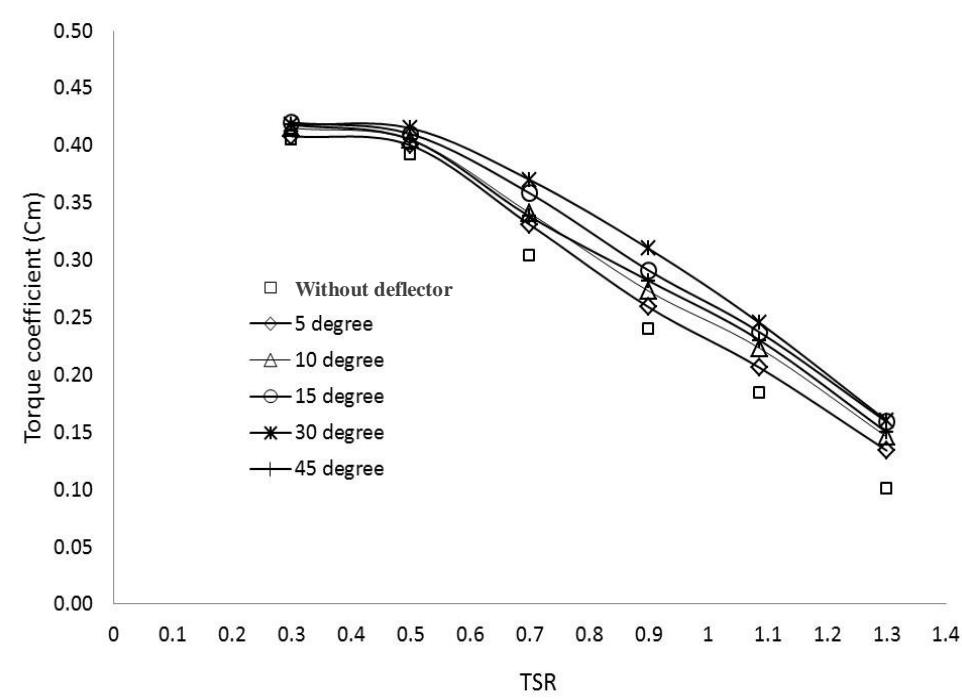

Figure 5. Tip speed ratio (TSR) as the function of Torque Coefficient $(\mathrm{Cm})$ 


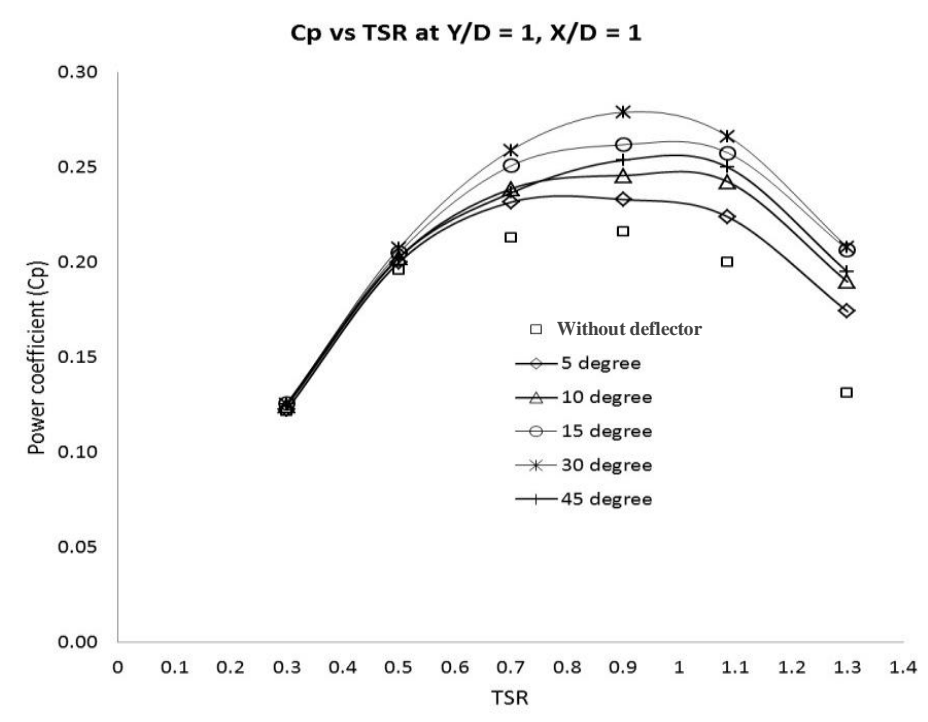

Figure 6. Tip speed ratio (TSR) as the function of Power Coefficient $(\mathrm{Cm})$

The result of numerical simulation as shown in figure 6 is Tip speed ratio (TSR) as function of power coefficient $(\mathrm{Cp})$. The value of power coefficient increased with the increasing of deflector angle at 30 degree. On the other hand, the value of power coefficient decreased with the increasing of deflector angle at 45 degree. The maximum power occurred at 30 of deflector angle.

\section{CONCLUSION}

Adding deflector to advancing blade side contributed great effect to the performance of Savonius turbine. From the result of above discussion, it shows that Savonius rotor which was modified by adding deflector to advancing blade side at $\mathrm{X} / \mathrm{D}=1$ and $\mathrm{Y} / \mathrm{D}=$ 1 influenced the torque coefficient and the power coefficient. A numerical investigation was conducted on a single stage Savonius rotor using sliding mesh at free stream velocity $0.22 \mathrm{~m} / \mathrm{s}$. The result indicated that there were changes to the flow characteristic. Obviously, by adding deflector in advancing blade side would influence the flow characteristic over the Savonius turbine and improved the torque coefficient and power coefficient at 30 of deflector angle. The present study also shows that the use of plate deflector to advancing blade side could increase the performance of Savonius turbine. Deflector angle increased the torque coefficient and maximum torque coefficient occurred at 30 of deflector angle.

\section{REFERENCES}

B. Fv Blackwell, Sheldahl, Robert E., and Louis V. Feltz. "Water tunnel performance data for two-and three-bucket Savonius rotors", Journal of Energy2, 1978, no. 3, pp. 160-164.

B. Launder, D. Spalding. "Lectures in Mathematical Models of Turbulence", Academic Press: Philadelphia, PA, USA, 1972.

B. Yang and C. Lawn, "Fluid dynamic performance of a vertical axis turbine for tidal currents", Renew. Energy, 2011, 36, pp. 3355-3366.

C. R. Patel, V. K. Patel, S. V. Prabhu, T. I. Eldho, "Investigation of Overlap Ratio for Savonius Type Vertical Axis Hydro Turbine”, International Journal of Soft 
Computing and Engineering (IJSCE), ISSN: 2231-2307, Volume-3, Issue-2, May 2013.

H. S. Hyun, C. Da-Hye, H. Jun .S and J. Yuan .J, "Performance Analysis and Design of Vertical Axis Tidal Stream Turbine", Journal of Shipping and Ocean Engineering 2, 2012, 191-200.

J. Freitas, "The Issue Of Numerical Uncertainty", second International Conference on CFD in the Minerals and Process Industries CSIRO, Melbourne, Australia, 6-8 Desember 1999.

K. Golecha, T. I. Eldho, and S. V. Prabhu, "Performance Study of Modified Savonius Water Turbine with Two Deflector Plates", International Journal of Rotating Machinery, Volume 2012, Article ID 679247, 12 pages, 13 January 2012.

K. Golecha, T. I. Eldho, and S. V. Prabhu, "Influence of the deflector plate on the performance of modified Savonius water turbine", Applied Energy, Vol. 88, no. 9,pp.3207 - 3217, 2011.

K. Pope, V. Rodrigues, R. Doyle, A. Tsopelas, R. Gravelsins, G. Naterer and E. Tsang, "Effects of stator vanes on power coefficients of a zephyr vertical axis water turbine", Renew. Energy, 2010, 35, 1043-1051.

O. B. Yaakob, D.T. Suprayogi, M. P. Abdul Ghani and K. B. Tawi, "Experimental Studies on Savonius-type Vertical Axis Turbine for Low Marine Current Velocity", IJE Transactions A: Basics Vol. 26, No. 1, pp. 91-98, January 2013.

P. R. Spalart and S. R. Allamaras, "A one equation turbulence model for aerodynamic flows", AIAA J, 1992, 94, doi:10.2514/6.1992-439.

S. Mc Tavish, D. Feszty, T. Sankar, "Steady and rotating computational fluid dynamics simulations of a novel vertical axis water turbine for small-scale power generation", Renew. Energy, 2012, 41, 171-179.

W. Tian, B. Song, Z. Mao, "Numerical investigation of a Savonius wind turbine with elliptical blades", Proc. CSEE, 2014, 34, 796 - 802. 